\title{
A LITERATURA NA ORGANIZAÇÃO DIDÁTICA DA ESCOLA MODERNA: EM UM CAMINHO DE PERDAS, A EXPRESSÃO DE UMA SOCIEDADE UTILITARISTA
}

\author{
Ana Aparecida Arguelho de Souza \\ Graciela Fátima Granetto
}

\section{RESUMO}

Trata este artigo da investigação da literatura e de seus instrumentos de ensino na organização do trabalho didático na escola burguesa. Assenta-se a discussão nos fundamentos da Ciência da História defendida por Marx e Engels em A Ideologia Alemã (1987, p. 23), que afirmam ser a história a única ciência efetivamente. Fundamentado na ideia de que é por meio da história que se pode apreender os objetos em sua gênese, desenvolvimento e obsolescência, este trabalho buscou captar, no contraponto com a Idade Média, a historicidade da literatura tal como ela se configurou em instrumentos didáticos específicos - manuais, compêndios e antologias - produzidos pela burguesia, ao longo do desenvolvimento do capitalismo. O objetivo foi delinear as perdas que sofreu a literatura nesse caminho, dentro de uma organização didática em que os instrumentos para o ensino da literatura, seguindo o espírito da escola manufatureira, relegou a literatura a um conteúdo sem expressão, feito de resumos e fragmentos. Para tanto procedeu ao levantamento e seleção desses instrumentos, buscando demonstrar por meio de sua análise, que na organização do trabalho escolar de nossos dias não há lugar para as altas literaturas que compõem o grande patrimônio cultural da humanidade.

Palavras chave: literatura; história; educação

\section{LITERATURE IN DIDACTIC ORGANIZATION OF MODERN SCHOOL: IN A PATH OF LOSSES THE EXPRESSION OF A UTILITARIAN SOCIETY}

\begin{abstract}
This article discuss about the investigation of literature and its tool of teaching in the didactic work organization in the bourgeois school. The discussion is based on the groundwork of Science of History, defended by Marx and Engels in "German Ideology" (1987, p. 23), who believed that the history is the only effective science. Grounded on the idea that it is through history that the objects can be learnt in their genesis, development and obsolescence, this work tried to capture as opposed to the middle age, the historicity of literature just as it has configured itself into specific didactic tools- manuals, compendiums and anthologiesproduced by the bourgeoisie, throughout the development of capitalism. The objective was to outline the losses that literature suffered during the path in a didactic organization in which the tools for literature teaching, following the essence of the manufacturing school, relegated expression, made of summaries and fragments. For this purpose it was carried out raising schemes and selection of these tools, seeking to show through its analysis that in the organization of school work in our day there's no place for great literature that makes the vast world cultural heritage.
\end{abstract}

Key words: Literature, history, education 


\section{Introdução}

Este trabalho é resultado de pesquisa acerca de manuais de ensino de literatura, em uma perspectiva histórica. O artigo apresenta o caminho percorrido por esta, a partir do contraponto entre a Idade Média e a Moderna, buscando apreender os determinantes materiais que demandaram sua presença em manuais didáticos, na organização do trabalho didático da escola moderna. Procura-se demonstrar como no interior dos manuais didáticos a literatura vai sendo descartada, perdendo conteúdo e substância estética, em uma nova organização do trabalho didático, que dela prescinde exatamente em razão do caráter utilitarista da sociedade do capital e do consumo rápido. Nesse caminho, seguindo as exigências da escola moderna, a literatura se torna uma fonte expressiva para se reconhecer, por ela, o caráter da sociedade que representa. Para tanto, se traça um rápido painel de sua estatura e características na sociedade medieval que antecede o capitalismo para, em seguida, apresentar como ela se materializa inicialmente nas pedagogias de Ratke e Comenius e em diferentes momentos das propostas pedagógicas burguesas, portanto, o início de um caminho de perdas. Em seguida, como se dá, no Brasil, uma espécie de vazio literário quando, no período compreendido de 1850 a 1950, as grandes obras consideradas patrimônio da humanidade cedem lugar a excertos literários, a pequenos textos de caráter prosaico e ufanista e a uma história da literatura, que ocupa seu lugar nos manuais didáticos. E, por fim, a migração dessa rasa literatura para o manual didático contemporâneo. O objetivo é evidenciar as perdas literárias no decorrer desse caminho. Ademais, quais circunstâncias históricas fizeram com que exatamente esse caminho fosse traçado.

\section{Literatura e educação na Idade Média}

Não se pode afirmar que na Idade Média houvesse uma escola única e universal, como decretou e estabeleceu, para si, a sociedade moderna. O que se percebeu, ao longo da investigação foram modelos educacionais se perfilando de acordo com as necessidades de cada estrato específico da sociedade medieval, embora houvesse predominância significativa do ideário da Igreja no imaginário de toda a população. Assim, a nobreza detinha para a formação de seus quadros o preceptorado, como a cavalaria definiu uma educação própria e adequada às suas necessidades específicas e o clero se organizou em torno dos mosteiros para uma educação clerical. Em cada uma dessas modalidades, a organização do trabalho didático ocorreu de forma diferenciada. Quanto à literatura, mesmo não se reconhecendo o termo em sua acepção moderna, pode-se dizer que na Idade Média, compreendida entre os séculos $\mathrm{V}$ e XV, existia já uma consciência da atividade literária.

A chamada Alta Idade Média, período em que predomina uma literatura de tipo monástico, segundo Spina (1997, p. 20), se reduz às hagiografias e aos poemas litúrgicos. O autor a denomina de literatura empenhada, "no sentido em que uma intenção pedagógica, didática, apologética, missionária, edificante, preside à sua elaboração". É uma literatura predominantemente caracterizada pela oralidade, considerando as dificuldades materiais da produção literária escrita, próprias da época. Em período posterior, informa o mesmo autor, as hagiografias e os poemas sacros coexistem com mais dois outros tipos de literatura, que ele classifica como semi-empenhada e de ficção.

A literatura semi-empenhada é um tipo de produção intermediária, com intenções satíricas e propósitos artísticos. Um exemplo desse tipo de literatura é a poesia goliardesca. Trata-se da poesia produzida pelos goliardos, intelectuais, ou vulgos intelectuais, despretensiosos, errantes, característicos do século XII. Segundo Le Goff (2010, p. 49-50) esses artistas 
[...] não dispõem de nenhuma prebenda, nenhum benefício, partem assim para a aventura intelectual, seguindo o mestre que lhe agrada, buscando aqueles que estão na moda, recolhendo de cidade em cidade migalhas de seus ensinamentos. [...] O jogo, o vinho, o amor: eis a trilogia que basicamente cantam.

Por último, a literatura de ficção seria a que se manifestava com evidentes intuitos estéticos, também conhecida como literatura desinteressada, como a poesia épica (canções de gesta e sagas escandinavas), a lírica trovadoresca, a poesia narrativa romancística e novelesca (romance cortês, cavaleiresco, de aventura e erótico-sentimental).

Embora essa distinção da literatura apresentada na Idade Média tenha sido feita por Spina, ratifica-se a força da Igreja na formação do homem medieval, bem como em tudo que o circunda, inclusive na literatura. Para Richard de Bury - que havia sido bispo de Durhan, chanceler do rei inglês Eduardo III - em seu Philobiblon, (2004), cuja primeira edição foi datada em 1344, todo livro era uma mostra da palavra divina, daí a relevância da literatura, nesse período. "É essencialmente por meio de cópias feitas na Idade Média que os autores da Antiguidade chegaram até nós. Copiar, ler, escrever, imitar, comentar Virgílio, Horácio, Ovídio ou Estácio é uma parte importante da atividade literária medieval" (LE GOFF, 2006, p.82).

No Philobiblon, o bispo de Durhan muitas vezes relaciona livros seculares com os textos bíblicos, defendendo a utilidade dos primeiros para se chegar à compreensão dos textos sagrados.

[...] como observou Cassiodoro em seu livro Instituição das Divinas Letras, não devemos depreciar as pequenas coisas, sem as quais as grandes não existiriam. De tudo isso se deduz que a ignorância pela poesia impedirá a compreensão das obras de São Jerônimo, Santo Agostinho, de Boécio, de Lactâncio, de Sidônio e de outros tantos, cuja simples enumeração requereria um extenso capítulo.[...] sendo o estudo dos poetas algo que pode trazer certo proveito, nada teremos perdido se o realizarmos [...]. (BURY, 2004, p.120-121)

Dois séculos antes do reverendo de Bury, Carlos Magno, numa carta que devia chegar a todos os bispos e a todos os mosteiros, afirma a importância que se dá à leitura e ao estudo da literatura "[...] nós vos exortamos, não somente a não negligenciar o estudo das letras, mas a aplicar-vos a ele com ardor e humildade agradável a Deus, a fim de poder penetrar mais facilmente e com mais segurança nos mistérios das Sagradas Escrituras" (PEDREROSÁNCHEZ, 2000, p. 171).

Ambas citações são importantes para se perceber a importância da atividade literária dessa época e como esta é reveladora da dominação que a Igreja exercia sobre a sociedade. Considerando, todavia, os outros estratos sociais que compunham a Idade Média, a produção literária representava também particularidades desses estratos.

Desta forma, a cavalaria, estrato social atrelado exclusivamente à nobreza, produzia a sua literatura com o objetivo de instruir os futuros cavaleiros. Um exemplo significativo é o Livro de Ordem de Cavalaria (2010), de Ramon Lull, escrito entre 1279-1283, que visava doutrinar os jovens da nobreza para tornarem-se grandes cavaleiros, apresentando as lições que deveriam saber para alçarem a condição de cavaleiro. Essas lições giravam em torno de variados assuntos, desde a origem da ordem, a exigências do pertencimento à mesma, instruções sobre a formação intelectual do cavaleiro, sua postura corporal, até mesmo sobre sua montaria. 
Também é importante considerar as Novelas de Cavalaria, que promoviam seus feitos e expressavam valores e concepções próprias da época. A origem desse gênero são as canções de gesta, narrativas orais sobre aventuras de guerras dos séculos VII a IX. Aqui, pomos em destaque as novelas que compõem o ciclo arturiano, que tinha como figuras centrais o Rei Artur e os cavaleiros da Távola Redonda. Todavia, inúmeras outras novelas compõem o importante acervo da literatura medieval e demonstram quão significativa é a atividade literária nesse período da história que antecede ao capitalismo, muito embora o Iluminismo o tenha tratado como o período de trevas.

Com este rápido painel acerca da literatura na Idade Média, espera-se ter dado sustentação para fazer o contraponto com a quase completa ausência da literatura, especialmente, das altas literaturas na organização do trabalho didático moderno.

\section{O ensino da literatura na modernidade: o início do caminho de perdas...}

Com a ascensão da burguesia e as modificações sofridas no campo do trabalho, que passa de artesanal a manufatureiro, uma nova literatura vai ganhando novas formas e, por meio de suas categorias estéticas, atestam as mudanças desse período de transição entre a sociedade medieval e a nova sociedade que vai sendo criada pela classe burguesa. Observese esta afirmação, ao comparar a figura do herói em Amadis de Gaula (século XIII ou XIV), com El Lazarillo de Tormes (1554) e, ainda, Dom Quixote de La Mancha (1605), de Miguel de Cervantes. O herói é a principal figura estética que marcou a presença do homem na literatura, tanto a antiga quanto a medieval, como expressão das nobrezas que comandaram essas duas sociedades.

Em Amadis de Gaula (1995), na figura do herói ibérico mais representativo do romance de cavalaria - o que se mostra é uma idealização dos ideais da cavalaria medieval. Uma fusão de expressão amorosa, heroísmo e religião. Ao contrário, tido como um pícaro, um anti-herói, apresenta-se Lázaro, cuja história, também de autoria desconhecida, critica a organização social em que vive e, principalmente, a instituição e os representantes da Igreja. Por isso, a obra foi proibida pela Inquisição, que permitiu apenas uma versão que omitia as passagens consideradas anticlericais. Lazarillo de Tormes (1992) pode ser publicado integralmente somente no século XIX. Ainda, pode-se encontrar outro anti-herói em Cervantes, com Dom Quixote (2004), figura caricata dos heróis da literatura de cavalaria, a atestar que a nova sociedade não se ergueu sem confrontos com a anterior e que, no campo cultural, a literatura é um atestado importante das lutas travadas entre ambas civilizações.

Outro bom exemplo dessa transição entre a sociedade feudal e a burguesa se pode encontrar no teatro de Gil Vicente, de uma época na qual a ordem social era inflexível, para uma nova sociedade onde se podia subverter a ordem ou pelo menos questioná-la. Em $O$ Auto da Barca do Inferno (1517) fica evidente o conflito entre o medieval e o moderno: ao mesmo tempo em que o autor confronta Deus e o Diabo, figuras emblemáticas da Idade Média, ele apresenta uma crítica social ao homem da época, mostrando uma forte tendência antropocêntrica e moderna, em detrimento à teocêntrica medieval.

Enquanto o texto literário já representava mudanças sociais ocorridas nesse período de transição entre uma e outra sociedade, com o trabalho didático não acontecia o mesmo. Até o século XVI, ele preservara suas características artesanais e essas teimavam em permanecer, como se fossem legados, porém já não eram mais pertinentes, existiam outras necessidades educacionais. $\mathrm{Na}$ verdade, a burguesia imitava a nobreza contratando preceptores para educar seus filhos, na mesma sistemática entre o preceptor e o discípulo, as aulas sendo ministradas geralmente em ambientes internos e externos da residência do discípulo ou da própria residência do preceptor. Muitas vezes, respeitadas as especificidades, 
contratavam-se diversos mestres, como também eram chamados, como se a ascensão da recém-formada classe, na visão dos próprios burgueses, dependesse de um "desempenho" nobre.

Confirma essa postura o teatro do dramaturgo francês Moliére (1622-1673) considerado um dos mestres da comédia satírica. Em O burguês fidalgo, escrita em seis atos, o autor faz uma crítica demolidora e bem humorada à burguesia, quando apresenta a extravagância do burguês Sr. Jourdain, a fim de se igualar socialmente a um nobre. Ainda no primeiro ato, o protagonista pergunta ao mestre de música se "as pessoas de trato também aprendem música" (MOLIÉRE, 1983, p. 299). Ao receber uma afirmativa como resposta, ele demonstra que está bastante empenhado: "Nesse caso, vou aprendê-la. Mas não sei de que tempo poderei dispor, visto que, além do Mestre de esgrima, que já começou a ensinarme, contratei também um mestre de filosofia, que deve principiar hoje cedo.” (p. 299)

Essa peça demonstra que, ao tempo de Moliére, a burguesia não mudara em relação ao método de ensinar e nem mesmo ao conteúdo, como aponta Alves (2005, p.59-60): "A relação educativa predominante continuava sendo aquela que colocava frente a frente $o$ preceptor e o discípulo".

Com o advento da modernidade, todavia, instaurou-se a necessidade de todos terem acesso à leitura e à escrita, cuja resposta constitui um dos alicerces do movimento protestante liderado por Martinho Lutero, culminado no início do século XVI. O acesso à Bíblia seria difundido e, com ele, um maior número de fiéis passaria a seguir as orientações da Reforma. "Intérprete da burguesia em grau maior do que pensava, Lutero compreendeu a estreita relação que existia entre a difusão da rede escolar e a prosperidade econômica" (PONCE, 1985, p.120) Afinal, quanto melhor preparada, mais condições a pessoa teria de ascender, considerando a modalidade do trabalho em detrimento à linhagem nobiliárquica.

Mesmo com o avanço da educação nos países protestantes, a instrução preceptoral não foi extinta, mas estendida aos pais, dando continuidade à base artesanal da ação educativa. Segundo Alves (2005), todavia, em paralelo ao trabalho dos preceptores, existiam iniciativas para que a educação rompesse com a relação educativa feudal, promovendo a divisão do trabalho.

Nesse intento, encontramos Wolfgang Ratke (séculos XVI e XVII), cujo princípio era o de oferecer instrução pública para todas as crianças, de forma coletiva, por meio de manuais: a educação do ponto de vista manufatureiro, que Comenius (século XVII), décadas depois, iria aprofundar. Pode-se dizer, então, que na obra Escritos sobre a nova arte de ensinar de Wolfgang Ratke (1571-1635): textos escolhidos encontra-se, de certa forma, a gênese da escola moderna e do manual didático.

A instrução coletiva é um ponto fundamental da pedagogia ratiquiana [...] Para o pedagogo a instrução comum ou coletiva favorece o ensino por darse para muitos alunos na mesma hora. Sua proposta de ensino inspirou-se na consciência social proveniente da produção material. A manufatura inicial, a produção de mercadorias mais avançada da época, resumia-se em que, sob o comando do proprietário, vários trabalhadores produziam a mesma peça, coletivamente, no mesmo local, ao mesmo tempo, utilizando as mesmas ferramentas. Essa forma de trabalho diminuía o tempo e os custos da produção. Ratke apresentou, à semelhança dessa divisão do trabalho material, sua proposta de divisão do trabalho didático: um único professor, com a presença de dezenas de alunos, num mesmo lugar e, utilizando o mesmo instrumento de trabalho, o manual didático, ministrava o mesmo ensino a todos, na mesma hora e ao mesmo tempo. Conforme ele próprio afirmou, o ensino tornava-se mais barato, com menor custo e 
tempo de aprendizagem. Utilizou, em larga escala, os manuais didáticos que se tornaram ferramentas do ensino e que permanecem na organização do trabalho didático até hoje. (HOFF, 2008, p.8)

Rakte foi, então, o primeiro a vislumbrar a necessidade dessa ferramenta de ensino. Nos primórdios do capitalismo, os manuais didáticos foram os materiais que orientaram a formação na escola burguesa. E exatamente esse modelo de escola e de instrumento didático foi necessário para consolidar como princípios a igualdade e a liberdade dos homens na sociedade. A escola foi uma das instituições que garantia essa igualdade, já que transmitia a todos o conhecimento, até então, monopólio da Igreja Feudal. A questão que se coloca é a qualidade do conhecimento a ser reivindicado e veiculado pelo manual didático.

Sabe-se que o objetivo maior de Ratke era promover a leitura em larga escala. Então, não se pode dizer que ele fundamentou, nem mesmo sistematizou um método de ensino como fez João Amós Comenius, em sua Didáctica Magna (1985), anos mais tarde. O objetivo de Ratke era específico, instrumentalizar os alunos para ler a bíblia na língua alemã, retirando o monopólio da bíblia, por meio do latim, das mãos da igreja católica para difundir a religião aos modernos em língua materna.

O contraponto é exatamente este: enquanto na Idade Média a igreja detém o monopólio do conhecimento, a pedagogia de Ratke e, em seguida, a de Comenius se propõem difundi-lo a todos e o que torna isso possível é o manual didático. Por aqui, iniciase o caminho de perdas da literatura.

Em Ratke, os textos aos quais os alunos tinham acesso eram retirados da Bíblia. Em termos de literatura, o que se encontra mencionado são apenas seis comédias de Terêncio, traduzidas do latim para o alemão pelo próprio Ratke. No mais, provérbios, evangelhos e outros textos bíblicos como ferramentas de leitura "a fim de que se possa entender as línguas, o Novo e o Velho Testamento e possa meditar sobre o temor a Deus e permanecer nele" (RATKE, 2008, p. 34). O ensino da língua alemã era um dos maiores objetivos de Ratke, considerando a importância das línguas nacionais frente à superação do idioma latino.

[...] as línguas nacionais vão se erguer juntamente com o surgimento e consolidação dos estados nacionais independentes, estados que constituem condição para o desenvolvimento do mercado mundial. Daí que a leitura como técnica de domínio da comunicação pelo indivíduo deveria necessariamente conduzir à instrumentalização das línguas nacionais. Por meio destas é que se estabelecerão as negociações e trocas necessárias ao desenvolvimento do capitalismo. (SOUZA, 2010, p.10)

Dessa forma, a superação do latim, língua oficial da igreja, representava mais do que não ser dependente do conhecimento de uma língua, era sim uma superação das amarras com que a sociedade feudal engessava a sociedade, no que tange não só à religião, mas à política e à economia. Por isso, numa hierarquia estipulada por Ratke (2008, p. 28-29) sobre as línguas que se deveria ensinar, o latim aprece em quarto lugar, ficando atrás das línguas alemã, hebraica e grega, estas duas últimas como forma de combate à Igreja Medieval.

A Didáctica Magna (1985), de Comenius, no capítulo XXII, Método para ensinar as línguas, também apresenta essa necessidade de aprender línguas, de forma segmentada: "[...] a língua materna, para tratar de negócios domésticos; as dos países vizinhos, para entrar em relações com eles [...]; para ler livros sabiamente escritos, a latina [...]; para os filósofos e para os médicos, a grega e a arábica; para os teólogos, a grega e a hebraica" (COMENIUS, 1985, p. 331). 
$\mathrm{O}$ autor fala sobre o pragmatismo desse aprender e sobre a divisão dos livros didáticos, conforme a faixa etária: $O$ vestíbulo, para a idade infantil; A porta, para os infantojuvenis; $O$ palácio, para a idade juvenil e $O$ tesoiro, para a idade adulta. Nos três primeiros há a orientação de como a língua deve ser ensinada gradativamente: por vocábulos, pequenas frases, trechos maiores e, no último, por meio de excertos de autores clássicos. Comenius (1985, p. 373) condena os autores clássicos: “O amor da glória de Deus e da salvação dos homens impele-nos a tratar com zelo este assunto, pois vemos que as principais escolas dos cristãos professam Cristo apenas de nome e, de resto, não põem as suas delícias senão nos Terêncios, Plautos, Cíceros, Ovídios [...]". Tal como o título, o capítulo é extenso. São 26 páginas (373-399), nas quais Comenius defende o texto bíblico em detrimento aos clássicos universais:

Para terminar: aqueles autores (Terêncio, Cícero, Virgílio, etc.) que se pretende oferecer à juventude cristã, em vez da Bíblia, são tais como eles afirmam que é a Sagrada Escritura: difíceis e menos inteligíveis que ela para a juventude. Efetivamente, não foram escritos para adolescentes, mas para homens de juízo maduro, que se movem já no palco ou no foro. Aos outros, de nada aproveitam, como o provam os factos. É certo, com efeito, que um homem feito e que procede virilmente, uma só lição sobre Cícero aproveita mais que um adolescente que o aprenda todo, linha por linha. Porque é que então se não remete para um tempo oportuno o estudo desses clássicos importantes, se de fato são importantes? (1985, p. 396-397, grifos nossos)

Atente-se para o questionamento, explícito na citação, acerca da importância ou não da literatura clássica. Como o clássico, o próprio preceptor perdeu seu espaço. A escola moderna precisava de mais trabalhadores para exercer a função de ensinar, afinal a "educação era para todos", mas não havia tantos homens de formação reconhecida. Por isso, Comenius desenvolveu o manual didático, cujo trabalho objetivado permitia qualquer pessoa de mediana instrução exercer o ensino. Com ele, uma nova organização didática, desde o nivelamento por idade, o espaço físico da sala de aula e a negação ou uso inadequado dos textos literários clássicos.

\section{Um século de vazio literário no ensino de língua e literatura (1850 - 1950)}

Em relação ao ensino da língua e da literatura, essa nova organização didática comeniana chegou e se instalou no Brasil, muito embora mediada pela cultura ibérica, que vai influenciar fortemente o ensino de literatura, como se pôde constatar ao examinar os instrumentos didáticos de ensino de literatura do Colégio Pedro II, aqui selecionado como locus da investigação pelo fato de ter servido de referência para os currículos das demais escolas das Províncias e, no início da República, dos Estados.

No currículo do Colégio Pedro II, a literatura só aparece como disciplina, com o nome Literatura Nacional, em 1862, ano em que foi publicada a primeira edição do manual Curso Elementar de Litteratura Nacional, do religioso Joaquim Caetano Fernandes Pinheiro. No entanto, a julgar pelos estudos de Vechia e Lorenz (1998, p. 3) conteúdos de literatura estavam arrolados pelo menos desde 1850, no programa de Retórica do sétimo ano. Segundo descrição desses pesquisadores, o conteúdo da Retórica partiu dos gêneros lírico, épico e dramático - definidos por Aristóteles - e foi ilustrado por diversos autores grecolatinos, europeus, de Homero, Virgílio, Lucano, Tasso, Ariosto a Camões, Fenelon, Voltaire e Milton. Inserindo ainda em 1850, Santa Rita Durão, com O Caramuru. É preciso deixar 
claro que esses, junto com outros autores clássicos, compõem uma listagem com 40 tópicos, o que não significa que os textos literários enumerados chegaram efetivamente à sala de aula, afinal, o Programa de 1850, transcrito por Vechia e Lorenz (p. 3), não faz referência nem a instrumento didático nem mesmo ao professor dessa cadeira. Ademais, as orientações sobre Retórica traziam de textos clássicos, apenas exemplos de como podiam ser usados como conteúdos ilustrativos de Retórica. Uma boa referência são as Postillas de Rethorica e Poetica (1885), de autoria do cônego Joaquim Caetano Fernandes Pinheiro. Portanto, qualquer inferência, com relação à leitura de obras completas de literatura nas aulas de Retórica nos anos 1850 e 1851, não pode ser considerada mais do que hipótese.

Também no Programa de 1856 - quando se faz menção aos livros Lições de Literatura e Quadros da litteratura nacional, para o $6^{\circ}$ ano de Retórica e $7^{\circ}$ ano, respectivamente, ambos do professor Francisco de Paula Menezes - a literatura serve de pretexto para outros saberes que não a formação humana decorrente de uma leitura total da obra. Assim, o programa propõe um trabalho com frases que exemplifiquem o uso correto de normas da retórica, procedimento constatado ao longo da história do ensino de gramática, nas escolas, o que é compreensível, dado que os conteúdos de Retórica e Gramática acabam se confundindo no currículo do Colégio Pedro II.

O respectivo Professor, depois de explicar durante o anno, as regras mais importantes da rethorica, acompanhando-as sempre de exemplos dos principaes escriptores, oradores, e poetas, antigos e modernos, e mais especialmente dos gregos, latinos e portuguezes, as resumirá, no fim do curso [...] (VECHIA e LORENZ, 1998, p. 37, grifos nossos)

O resumo mencionado no programa de Retórica do sexto ano deveria partir de oito questões elencadas, desde estabelecer a diferença entre poesia e versificação, até citar as qualidades "geraes do estylo com citações mais especiaes dos classicos de nossa lingua" (p.37). Para o sétimo ano, "os alumnos comporão trabalhos litterarios sobre diversos assumptos, exercitando-se assim em escrever elegantemente e procurando imitar os modelos indicados pelo professor" (VECHIA e LORENZ, 1998, p.40). Tais anotações confirmam que o ensino de literatura apresentado nos programas de Retórica, tinha outras finalidades que não a leitura completa dos textos com intenção de considerar o seu caráter humanizador.

Quanto aos instrumentos didáticos citados, a hipótese é que seguiam as orientações do Programa de Ensino, porém não foi possível consultá-los, já que não foram encontrados. Ao que se sabe, o professor Francisco de Paula Menezes não havia publicado esse material. É o que se pode depreender de Joaquim Manuel de Macedo, em Um passeio pela cidade do Rio de Janeiro:

Deixou numerosos discursos impressos e também diversos manuscritos, entre os quais alguns infelizmente incompletos. Compôs, e não sei onde param, uma tragédia em verso endecassílabo intitulada Lúcia de Miranda, um drama e uma comédia que tinha por título $A$ noite de $S$. João na roça. Sobressaíam entre esses manuscritos os quadros da literatura brasileira, a que faltava a última parte, de que ele mais fervoroso se ocupava, quando foi atacado pela enfermidade que o levou à sepultura em 1857, tendo então apenas quarenta e seis anos de idade. (2005, p. 351)

Após o falecimento do professor Francisco de Paula Menezes, embora Vechia e Lorenz não apresentem essa informação, suspeita-se que, um ano depois, é o Cônego Joaquim Caetano Fernandes Pinheiro quem ocupa a cadeira de Poética e Retórica, segundo 
o próprio cônego ao justificar a elaboração do Curso Elementar de Litteratura Nacional. "Quando em 1857 fomos nomeado professor de rethorica, poetica e litteratura nacional do Imperial Collegio de Pedro II, reconhecemos practicamente a falta d'um compendio adaptado à ultima parte do nosso curso" (PINHEIRO, 1862, s/d).

O referido compêndio foi publicado em 1862, com a implantação da Litteratura Nacional como disciplina. A obra é dividida em 43 lições de história da literatura portuguesa, apenas a última lição fazendo referência clara à literatura brasileira, embora o autor justifique que nas lições anteriores:

Nem-uma distincção havemos até agora estabelecido entre os dois povos que, através do Atlantico, fallam a lingua de Camões: dividindo em escolas a sua litteratura, classificamos indistinctamente nellas brasileiros e portuguezes conforme entendemos pertencerem-lhes seus escriptos. (PINHEIRO, 1862, p. 533)

O que fica evidente, ao analisarmos o manual didático, é que aos textos literários não é dada nenhuma relevância. A historiografia é descrita e fragmentos literários são utilizados como exemplificação do que se está afirmando. Exemplo claro é ao apresentar o poeta Domingos José Gonçalves de Magalhães (1811-1882), não se dar ênfase à epopeia $A$ Confederação dos Tamoios (1856), embora utilizar-se dela, por meio de fragmentos, para dizer o que essa publicação representava.

Reflecte nestes versos a natureza brasilica, e ninguém ao le-los poderá duvidar da nacionalidade do poeta. Tudo aqui é nosso; os assumptos, os nomes, [...]. É com producções d'esta ordem que incontestavelmente firmaremos a nossa independência litteraria. (PINHEIRO, 1862, p. 541)

Infere-se, então, que a literatura continua sendo utilizada como pretexto, agora não mais para exemplificar regras de retórica, mas para destacar o ponto de vista histórico, dando prosseguimento ao vazio literário apontado no século em questão (1850-1950). O ensino da literatura atrelado à tradição ibérica, expressando, de certa forma, o colonialismo à literatura portuguesa, vai ser questionado e rompido, posteriormente, com a publicação da História da litteratura brasileira, de Sílvio Romero, em 1892.

Nesse ínterim entre a publicação do cônego e a de Sílvio Romero, outros autores apareceram nos programas levantados por Vêchia e Lorenz (1998): Theofilo Braga, Manual da Historia da Litteratura Portugueza; Fausto Barreto e Caldas Aulete, Selecta Nacional; Midosi, Poesias Selectas (p.80); Ferdinand Wolf, Le Brésil Littéraire/Histoire de la Litterature Brésilienne (p.89); e o retorno do Cônego Fernandes Pinheiro com outro compêndio, Historia Litteraria (p.106).

Em 1892, entra no Programa de Ensino, a Historia da litteratura brazileira, de Silvio Romero, citada como Apostillas do professor (VÊCHIA, LORENZ, 1998, p.121). Todavia, Luiz Antônio Barreto, na Nota do Organizador da edição comemorativa do Compêndio de História da Literatura Brasileira (2001), informa que a História da Literatura Brasileira, na forma de compêndio foi publicada pela primeira vez em 1888, de modo que as informações investigadas são contraditórias. De qualquer forma, mais importante é perceber a orientação positivista e naturalista de Silvio Romero, o que difere sua obra da do Cônego Fernandes Pinheiro, adotada anteriormente no Colégio Pedro II.

Bastante diferente da proposta do cônego Fernandes Pinheiro para a literatura é a de Silvio Romero, claramente um intelectual afinado com as 
novas reflexões teóricas oriundas da orientação positivista e naturalista importadas da Europa. O Compêndio de Literatura Brasileira, sem dúvida, representa, no campo da literatura, a máxima expressão do positivismo no Brasil que, desde o final dos oitocentos até o surgimento do formalismo russo, fincou os estudos literários no campo da história. [...] a história da literatura, a partir do último quartel do século XIX, ganha expressão como síntese do desenvolvimento histórico de um povo, que encontra nela a expressão de uma identidade própria, a partir das determinações do meio, das heranças culturais, da sua evolução e das raças presentes em sua formação. (SOUZA, 2012, p. 6)

Sílvio Romero, seguindo a orientação positivista, mantém a discussão da literatura no leito da história, dessa feita, captando-a como resultante de determinações externas o que justifica, ao longo da obra, a discussão de cada uma dessas tendências ao invés de trazer a literatura em si, como conteúdo.

Em 1895, aparece no currículo outro instrumento didático, a antologia literária. Nesse momento, se tem a impressão de que a literatura ocupará finalmente o seu lugar na organização do trabalho didático com a literatura, já que uma antologia, diferente de um manual didático ou de um compêndio, se presta à reunião de textos literários. A primeira que se tem notícia é a Antologia Nacional de Fausto Barreto e Carlos Laet que circulou até 1969. Sua gênese, ao que sugere o prefácio da primeira edição, é ainda anterior. Em 1887, Fausto Barreto e Vicente de Souza publicaram a Seleção Literária a qual apresentava textos de poetas e prosadores, brasileiros e portugueses.

Convidados pelo prestimoso editor J. G. De Azevedo para corrigir a Seleção literária compilada por um dos coletores dessa antologia e outro professor, mais acertado nos pareceu refundi-la de todo, dando-lhe a forma que ora à deparamos à publicidade. (BARRETO e LAET, 1951, prefácio da $1^{\text {a }}$ edição 1895 )

Ainda no prefácio dessa $1^{\text {a }}$ edição (1895), os autores, embora tenham usado como subtítulo da obra a explicação do título - coleção de excertos - justificam-no:

$\mathrm{O}$ título de Antologia muito de indústria o adotámos. Se os vocábulos podem ter cheiro, êste é de certo um dos mais odoríferos. Em seus dois elementos efetivamente reúne a ideia da flor e a da palavra, que é a flor do entendimento. Não havia senão os Gregos para formarem vocábulos como êsse! Aproveitemo-lo. E êle também prevenirá o leitor benigno de que se não escandalize de quaisquer lacunas. Um ramilhete não é um horto botânico. Basta que formosas e aromáticas sejam as flores aqui reunidas, e que oferecemos à mocidade de ambos os países onde se fala o português. (BARRETO e LAET, 1951, prefácio da $1^{\text {a }}$ edição 1895)

À medida que se vai publicando e reeditando, as antologias - também chamadas de seletas ou florilégios - vão perdendo sua essência de coletânea de textos literários, porque nelas vão sendo incluídas noções e exercícios gramaticais, de composição, e outras linguagens como a publicitária, por exemplo. Acrescente-se ainda a evolução das ilustrações, que nas anteriores não passava de uma ou outra ilustração de algum tópico da literatura, para essa gama de ilustrações que faz do manual contemporâneo um verdadeiro festival de cores e imagens, com prejuízo do texto. Assim, aos poucos, se vê surgir o manual didático contemporâneo, que segue a tradição comeniana. Cabe reafirmarmos o conceito de antologia exatamente para estabelecer a diferença com os manuais: 
[...] É importante diferenciar as antologias das demais modalidades, porquanto uma antologia para fins didáticos, ao compilar textos clássicos, não pode ser considerada um manual, já que sua preocupação primeira é acessar aos alunos o texto clássico. (SOUZA, 2010, p. 124-125)

Exatamente isso não ocorre com os manuais contemporâneos, o que nos remete à organização do manual didático comeniano. Para Comenius, os livros com a finalidade de ensinar uma língua devem ser quatro: Vestíbulo, Porta, Palácio e Tesoiro, apresentando, respectivamente, vocábulos e pequenas frases; cerca de 8 mil palavras e frases, regras gramaticais breves e simples; todo gênero de frases e regras; autores clássicos. Esse último, o Tesoiro, identifica-se facilmente com o ensino de literatura presente nos manuais contemporâneos, em uma relação que nos parece ainda mais simples e clara, principalmente ao se traçar as semelhanças. Assim Comenius descreve a metodologia contida no Tesoiro:

[o assunto] Deve ser precedido das regras sobre a investigação e a escolha das partes mais vigorosas de um discurso, assim como a tradução exacta dos idiotismos (que é uma das regras mais importantes a observar). Escolham-se alguns destes autores para ler nas escolas; dos outros, faça-se um catálogo [...]. (COMENIUS, 1985, p. 338)

Essa tendência apresenta-se na Antologia de Laet, utilizada no Colégio Pedro II, com o agravante de que, no plano das alterações curriculares provocadas por sucessivas reformas de ensino, a literatura como disciplina é extinta em 1912. Nesse momento, os estudos literários passam a ser apresentados somente à $4^{\mathrm{a}}$ série, na disciplina de português, com uma carga horária semanal de 3 horas. Divide espaço com revisão, gramática histórica, composição, sintaxe entre outros conteúdos e práticas. Para dimensionar essa redução, dos 19 tópicos apresentados no programa de português, apenas os dois últimos dizem respeito ao estudo da literatura. E, o mais grave, uma literatura restrita a fragmentos de textos portugueses e brasileiros, de caráter simplório e com alto teor ufanista.

Em 1926, a literatura enquanto disciplina volta ao currículo do Pedro II, com o nome de Literatura Brasileira. Era o que se esperava, já que ela passa a ser disciplina exigida no exame vestibular para o curso de Direito. Como isso, retorna também a indicação do livro de Silvio Romero, que permanece até 1930. No ano seguinte, a literatura volta a ser ministrada como conteúdo da disciplina de Português.

Essas variações são relevantes porque denotam a redução da carga horária destinada aos estudos literários. Isso se o que está no programa for realmente efetivado em sala de aula, se não, pensando numa eventual necessidade de se reduzir o número de tópicos, poderá ser ainda mais grave, pois provavelmente a exclusão se dará na literatura. Afinal, esta é subordinada à de Português.

A partir de 1931, além da literatura deixar mais uma vez de compor uma disciplina retornando como disciplina independente somente 40 anos depois - não se tem mais, segundo os programas elencados por Vechia e Lorenz (1998) referência sobre os livros utilizados no Colégio Pedro II. Pelo menos até 1951, último ano compreendido no levantamento dos autores.

Curiosa a ausência da disciplina de Literatura, principalmente em se tratando da década de 30, já que é o período em que se difundem os ideais democráticos da escola nova. Embora saibamos que estes foram gerados e fomentados num contexto mundial, chegam ao Brasil num momento também de efervescência, de passagem de um país agrário para um industrial, do poderio de uma classe dominante rural para urbana, da oligarquia para a 
burguesia e com forte apelo educacional de mudanças que envolvem, inclusive, a organização do trabalho didático e seus instrumentos.

Esses ideais pedagógicos são representados, principalmente pelos educadores Anísio Teixeira, Fernando de Azevedo e pelo norte-americano John Dewey (1859-1952). Este, considerado o fundador da Escola Filosófica do Pragmatismo, baseava sua teoria em experiências e práticas que instigam à aprendizagem, passando o foco a ser o aluno, suas necessidades e vontades, o que rompe totalmente com a pedagogia tradicional e seus instrumentos didáticos.

Dessa forma, pode-se compreender o porquê de os manuais didáticos ou "livros escolares" serem tão criticados nesse período. Fernando de Azevedo (1953, p.191) chega a chamá-los de "déspotas" pelos quais os alunos eram "escravizados", considerando, principalmente, sua função de regular todas as atividades do professor e do aluno.

Essa citação de Fernando de Azevedo é parte de seu discurso no encerramento da Semana do Livro, em 1933, no Instituto de Educação, da Universidade de São Paulo, publicado no livro A Educação e seus Problemas. Nesse discurso, pode-se observar a extrema relevância que é dada ao livro para a renovação educacional.

O livro de texto, na escola tradicional, e o livro escolar, na educação nova, distinguem-se apenas por uma diferença fundamental de função. Ele não desaparece da escola nova, mas assume uma "nova função", tão importante, tão larga e tão profunda, que já não bastaria, para cada matéria, o único livro: o livro de leitura, o livro de texto. [...] e ela possa ler, na biblioteca escolar, não o livro que se lhe impõe, mas de todo o seu alcance âqueles que lhe agrada ler, que a interessaram, por atenderem melhor aos seus gostos, às suas tendências e às suas necessidades. (AZEVEDO, 1953, p.192)

Considerem-se os claros preceitos do escolanovismo no que diz respeito à relação do aluno com o conhecimento. Quando Saviani (2008, p. 37), em Escola e Democracia afirma que "ensino não é pesquisa", ele traça a diferença entre a Escola Tradicional e a Nova: "[...] nos métodos novos, privilegiam-se os processos de obtenção dos conhecimentos, enquanto lá, nos métodos tradicionais, privilegiam-se os métodos de transmissão dos conhecimentos já obtidos." (Idem, p. 38). Na escola tradicional, os conhecimentos a serem transmitidos se materializam em obras do pensamento e da criação humana, inclusive, das altas literaturas já produzidas ao longo da história.

Todavia, tratam-se de ideias sobre uma proposta de Escola Nova, enquanto, na prática, a Antologia Nacional de Fausto Barreto e Carlos de Laet, por exemplo, permaneceu sendo publicada até 1963. Para exemplificar, tome-se a edição de 1951. A obra apresenta a seleção de textos por meio da indicação de seus autores, dividindo-os em prosadores $\left(1^{\mathrm{a}}\right.$ parte) e poetas ( $2^{\mathrm{a}}$ parte). Numa subdivisão interna dessas partes, apresentam-se os brasileiros, posteriormente os portugueses, de acordo com as seguintes fases: contemporânea, acadêmica, seiscentista, quinhentista, medieval, numa ordem descendente, se considerada a cronologia.

Com a continuidade de publicações tão próximas ou até iguais a que se tinha antes do escolanovismo, se pode inferir que a nova pedagogia não se concretizou para a literatura, já que continuou em vigor a mesma proposta de antologias com o mesmo teor dos textos.

\section{A migração dos excertos literários para o livro didático contemporâneo}

$\mathrm{Na}$ década de 60, pode-se dizer que houve esforços para se elaborar antologias que centrassem em textos literários, cujos aspectos estruturais e ideológicos de sua estética, 
conduziam a uma leitura, desta feita, esteticista. Destacamos duas antologias, a de Afrânio Coutinho, Antologia Brasileira de Literatura (1965), e a Marques Rebelo, Antologia Escolar Brasileira (1967). É bom destacar que o advento dos estudos formalistas e estruturalistas que vão ocorrer nos primórdios do século XX, vão, tardiamente, retirar a literatura das orientações historicistas do positivismo, conduzindo o olhar do pesquisador para as entranhas do texto literário. Como a escola lidou com essa guinada nos estudos literários é o que se verá a seguir.

Para melhor compreensão, retrocede-se a 1952, ano em que Afrânio Coutinho assume a cátedra de literatura do Colégio Pedro II e, em seu discurso de posse, defende uma ruptura do modelo de ensino literário, substituindo o ensino historiográfico pelo estudo dos gêneros.

Em 1965, ele lança a $1^{\text {a }}$ edição da Antologia Brasileira de Literatura, nos dois anos que seguem publica as $2^{\mathrm{a}}$ e $3^{\mathrm{a}}$ e, em 1970, a $4^{\mathrm{a}}$ edição - que se utilizará nesta análise. A obra foi organizada em três volumes, segundo os seguintes gêneros literários: Romance e Conto (Volume I); Lirismo (II) e Epopeia, Teatro, Ensaio, Crônica, Oratória, Máximas, Cartas, Memórias, Diários e Crítica (III).

No primeiro volume, há uma Introdução Geral que muito recupera do discurso pronunciado em 1952, sobre o qual já se comentou. Ao final, dessa introdução, o autor defende a obra integral em detrimento dos textos fragmentados.

O ideal do estudo literário é fazê-lo sôbre obras integrais. Uma antologia não se presta para esse objetivo, a não ser em alguns gêneros como o conto, o lirismo, a crônica. Procurou-se, tanto quanto possível, obedecer a êsse critério. No mais, a antologia não passa de uma escorva, provocando ou conduzindo aos textos completos, ao que devem sempre orientar os professôres. (COUTINHO, 1970, p. XIV)

Nesse ponto, percebe-se uma nítida ruptura com as antologias anteriores. O que segue, na obra, traz explicações sobre a ficção, seus gêneros, bem como cada elemento da narrativa. São 22 páginas com o que se descreveu até aqui, e 323 com textos literários, trechos de 27 romances, de José de Alencar a Jorge Amado; e 23 Contos, de Bernardo Guimarães a Clarice Lispector.

Depois da apresentação dos textos, todos introduzidos por uma curtíssima biografia, bem como a bibliografia de cada autor, Afrânio Coutinho apresenta um questionário com 61 questões ligadas à estrutura, temática e estilística:

O estudo dos textos acima apresentados, além da leitura simples e da dramatização, deve ser feito à luz de questões ligadas à estrutura, temática, estilística, da obra de ficção. Há que encaminhar o espírito do aluno para a solução e boa compreensão dos problemas fundamentais da ficção, tendo em vista a experiência dos grandes ficcionistas, segundo a técnica pessoal e as sugestões da escola ou estilo a que pertenceram. [...] É mister não esquecer a regra de que a leitura deve ser feita de textos tanto quanto possivel completos. (COUTINHO, 1970, p. 325, grifos nossos)

A segunda antologia aqui mencionada, a Antologia Escolar Brasileira (1967), de Marques Rebelo, como a de Coutinho, defende a leitura integral do texto e assinala o fato de conseguir publicar uma antologia com um grande número de textos integrais - dentre eles uma comédia - uma "novidade": 
Há novidades, como a que nos permitimos sublinhar: a vantajosa quantidade de textos integralmente transcritos - contos, crônicas, cartas, discursos, prefácios, capítulos de romances, grandes poemas e até uma comédia inteira de Martins Pena, famosa nas grandes letras teatrais, mas da qual sempre foi praxe antológica apresentar pequenas cenas, incapazes de espelhar o mérito do criador do teatro brasileiro - procurando com êsse expediente despertar ou mais aguçar o interêsse dos jovens. (REBELO, 1967, p.7)

Por meio da defesa do texto integral, relacionamos com tranquilidade essas duas antologias, embora, a partir daí, elas se diferenciem. Em Afrânio Coutinho percebe-se uma preocupação sobre a compreensão estética da obra. Não percebemos o mesmo em Marques Rebelo, já que ele apresenta textos de 111 autores seguindo um critério cronológico descendente, dos mais recentes, os poetas Carlos Pena Filho e Mário Faustino, aos mais antigos, Frei Vicente do Salvador e Anchieta, sem estabelecer distinções estéticas.

Terminada a exposição das duas antologias que compactuaram com a integridade do texto, bem como os esforços de seus autores em romper com o que se tinha até aquele momento, ilustraremos a seguir a migração dos textos literários, das antologias para o manual didático contemporâneo, com a obra, Ciclo ginasial de português, de Rocha Lima (1970).

Carlos Henrique da Rocha Lima tornou-se catedrático de língua portuguesa no Colégio Pedro II, em 1956. O Ciclo ginasial de português é composto por 33 lições, cada uma com três seções. A primeira e a segunda são intituladas como se fossem convites: Vamos ler?, Vamos escrever? e a terceira Gramática e Exercícios. A primeira seção, objeto de nossa análise, apresenta textos de autores contemporâneos, com exceção a Camões. A migração se dá pelo retalhamento e encurtamento dos textos, para dar lugar às seções de escrita, gramática e leitura, que se fazem presente de forma muito mais ampliada do que nas antologias do início do século XX, disputando espaço com o texto literário. São 35 textos literários, entre romances, contos, crônicas e poemas, alguns apresentados na íntegra, a maioria fragmentados, todos seguidos do glossário intitulado Para facilitar a leitura.

$\mathrm{O}$ autor não faz distinção quanto aos gêneros literários, nem a qualquer elemento estético. Em muitas lições há relação entre o texto literário e a proposta de produção textual da seção Vamos escrever?, indiciando um procedimento comum ao ensino de retórica, qual seja, oferecer padrões textuais que sirvam de modelo à boa escrita e à oratória. Outras vezes, ocorre a correspondência entre trechos do texto com explicações ou exercícios gramaticais.

A par do encurtamento textual, o manual em questão apresenta outras características muito próximas às dos manuais contemporâneos. A começar pela coloquialidade e pela função apelativa da linguagem utilizadas no título das primeira e segunda seções, Vamos ler? Vamos escrever? já demonstrando uma tentativa de "seduzir" o aluno. Esse, que é um procedimento comum nos manuais contemporâneos, sofre a crítica demolidora de Osman Lins (1977). No capítulo “A arte da sedução”, de seu livro Do Ideal e da Glória: problemas inculturais brasileiros o literato critica o modo como, na introdução dos manuais, os autores se dirigem aos alunos. "Tal introdução, parece, transformou-se em norma; e o tom, aí, é sempre ameno e aliciador, sem perder de vista certos recursos usuais dos técnicos de vendas" (LINS, 1977, p.127).

A apresentação do manual "Ao aluno" é outra exemplificação claríssima do que fala Osman Lins quanto à sedução, como no caso:

Este livro foi pensando em você, jovem de hoje, que gosta de música, esporte, cinema, TV, que participa, enfim, intensamente do tempo que 
estamos vivendo [...] Não há esquemas rígidos, nada é obrigatório neste livro. [...] poderá escolher entre as atividades propostas a que lhe agradar mais. Nosso livro é tão aberto, como os ideais da escola brasileira moderna. (ROSA, NOGUEIRA, 1976, p. 9)

Aliada, novamente, ao tom da linguagem sedutora, tal qual um vendedor, há uma permissividade exagerada que beira a negligência com o próprio conhecimento, ameaçando ou, pelo menos, tornando questionável a qualidade da obra.

Também a organização do manual denota semelhança com os contemporâneos, já que nestes as lições podem ser relacionadas às unidades, em sua maioria, subdivididas em seções. E ainda, no que respeita ao texto literário servindo de pretexto para aprendizagem linguística, ao invés de ser explorada sua estética ou temática, imprescindíveis à compreensão literária, primeiro passo para a apreensão do mundo e do homem na obra, portanto, para uma leitura humanizadora.

Não só o texto evolui e migra das antologias para os manuais contemporâneos, mas também as ilustrações das primeiras antologias vão ganhando corpo e cor. Osman Lins chamou esse fenômeno de disneylândia pedagógica, o excesso de desenhos com observações, muitas vezes, estúpidas. Como o caso da figura de uma vírgula personificada. "Lembra-se de mim? Meu nome é vírgula! Sou um sinal de pontuação que indica uma ligeira pausa na leitura?" (LINS, 1977, p. 136). Claro que muitos manuais analisados não chegam aos delírios iconográficos referidos por Osman Lins, mas trazem imagens totalmente dispensáveis. Como por exemplo, em um dos manuais examinados, na apresentação de um fragmento de Madalena, trecho do livro São Bernardo de Graciliano Ramos, quase meia página é tomada por uma figura que ilustra um pôr do sol no mar (ROSA, NOGUEIRA, 1976, p.189). Outro exemplo, antes do poema Veículos de Massa TV, de Mário Chamie, a ilustração de um olho, com um pano de fundo azul claro (Ibidem, p.214).

Retornando à obra de Rocha Lima, como ilustrativa dessa passagem das antologias aos manuais didáticos contemporâneos, pode-se dizer que sua antologia segue as de Afrânio Coutinho e a de Marques Rebelo, quanto à negação da historiografia, porém aproxima-se, sobremaneira, dos manuais didáticos contemporâneos, quando revela um desmantelamento do texto literário, ilustrado pela fragmentação constante, pelas ilustrações pueris, e pelos usos e abusos que dele fizeram.

\section{Considerações Finais}

A análise das fontes aqui apresentadas, face aos objetivos propostos, permitiu confirmar algumas características que, nos manuais contemporâneos, remetem ao seu caráter conservadorismo e comprometimento com uma pedagogia burguesa que se inscreveu na sociedade, desde os primórdios.

A primeira é que a apresentação da Literatura tem seguido a sequência historiográfica tradicional e que essa organização do trabalho didático de literatura exclui qualquer outra possibilidade de apreensão de textos nos manuais analisados. Decorrente dessa, constata-se a negação de espaço ao texto literário, espaço que é ocupado por comentários sobre fatos históricos do período em que a obra foi escrita, dados sobre o autor, ou seja, informações extra literárias que muitas vezes beiram a especulações.

Outra característica encontrada nos manuais didáticos contemporâneos são os resumos. Ao se apresentar o resumo de um enredo, por exemplo, perde-se muito da totalidade da obra, a apreensão dos detalhes é extremamente prejudicada. Tratando-se especificamente dos alunos do $3^{\circ}$ ano do Ensino Médio, que estão na reta final de preparação para vestibulares e ENEM (Exame Nacional do Ensino Médio) o resumo das obras listadas, 
de certa forma, atende o imediatismo desse tipo de avaliação, já que as questões não requerem um nível profundo de compreensão que, obviamente, só se depreende com a leitura integral da obra literária. Ademais, a linguagem do resumo a literária são distintas. A literatura não se dá apenas do plano do enredo, que é o que mostram os resumos. Fica-se com a historinha, perde-se a literatura.

Fato é que o manual didático contemporâneo teve sua gênese no século XVI e é por meio da história desse instrumento didático que compreendemos essas características: a abordagem resumida do texto literário foi defendida por Comenius, no capítulo XXXI da Didáctica Magna (1627-1644), para se evitar o "estudo penoso" (1985, p.449) e para quem não tem tempo disponível para leituras integrais, ou ainda, para uso dos mais pobres:

Estes resumos dos autores teriam uma grande utilidade. [...] para aqueles que não têm tempo para ler obras extensas, para que ao menos adquirissem um conhecimento geral desses autores [...]. Poderiam esses sumários dos autores ser editados em separado (para uso dos mais pobres ou daqueles que não têm possibilidades de estudar integralmente os grandes volumes) e, depois, serem juntados aos respectivos autores, para que, quem se prepara para ler uma obra inteira, possa primeiro apreender o resumo de toda ela. (COMENIUS, 1985, p. 450-451)

As ideias utilitaristas do texto literário, a literatura esquartejada, alijada, principalmente dos alunos das escolas públicas que têm no manual didático contemporâneo a única porta de acesso à literatura, são elementos que vêm, de séculos, enraizados nesse instrumento, perpetuando a lógica da sociedade do capital.

Na mesma direção, mais uma característica do manual didático contemporâneo é a fragmentação, pois quando esse instrumento não nega ou resume o texto literário, fragmentao. E essa gênese está na recomendação de Comenius em não se "atulhar a cabeça dos alunos com textos inteiros". (1985, p.237).

Ainda no percurso histórico da fragmentação, ao passo que a educação se universaliza, há a necessidade de facilitar, simplificar o trabalho do professor, considerando que este, além de atender a classes numerosas, muitas vezes não era formado para o trabalho com as obras clássicas, como o eram os preceptores. Como pontua Alves,

Para Comenius, então, tratava-se e simplificar e objetivar o trabalho didático, de tal forma que qualquer homem mediano pudesse ensinar. Até então, o mestre, na condição de preceptor, era uma figura cujo conhecimento ia muito além da média dos homens. (ALVES, 2001, p.88)

O leito da história consegue então, explicar esse fato, já que Comenius está no século em que o trabalho manufatureiro supre o artesanal, e é nesse processo de objetivação do trabalho que emergem os manuais contemporâneos, cujas características, considerando o movimento histórico, estão presentes.

A fragmentação, que nas antologias de Afrânio Coutinho e de Marques Rebelo parecia incomodar, consideradas as inúmeras vezes que os autores defenderam a leitura do texto integral, na atualidade, é recorrente nos manuais didáticos, sendo, inclusive, titulada no sumário, como "Fragmento".

Sabe-se que os manuais não comportariam alguns gêneros literários integralmente, como o romance, por exemplo, mas se fragmentar poemas, como é o caso de Tabacaria, de Álvaro de Campos e também de Dispersão, de Mário de Sá-Carneiro, não é passível de justificativa. Não que sejam poemas curtos, mas poderiam ser contemplados em sua 
totalidade sem muito esforço, em detrimento, talvez, da disneylândia pedagógica despropositada, dos resumos cinematográficos altamente divulgados - como se o cartaz ou fotografias de algumas cenas de filmes fosse essencial para despertar o interesse sobre o assunto.

Retomam-se, então, as características do manual didático contemporâneo elencadas nesse estudo - negação, resumos e fragmentos - sobre as razões, indiscutivelmente, históricas desse instrumento didático, que são apontadas pelo pensamento marxista.

[...] é possível pensar no século XX como aquele período no qual ocorre o lento processo de decadência do modo burguês de produzir a vida. Período em que toda uma civilização perde seus parâmetros [...]. Esses estudos estão sustentados em fatos concretos: desemprego, acompanhado de esforços e tentativas de inúmeras formas de trabalho alternativo, o que indica o esfacelamento da relação capital x trabalho. Ainda, irracionalidade e fragmentação das linguagens e dos conhecimentos, [...]. (SOUZA, 2010, p.129-130)

O esfacelamento da literatura nos manuais didáticos contemporâneos, por meio da leitura fragmentada, incompleta, inacabada, dos pedaços de textos cada vez mais curtos, trechos ou resumos, quando não apenas informações, ilustrações sobre o que seria o texto literário é uma das marcas de uma sociedade que, além de se apresentar fragmentada, se desmancha. "Esse desmanchar inexorável expressa-se na diluição de todos os elementos, [...], inclusive da escola, seu espaço físico, a relação entre professores e alunos e seus instrumentos, incluído o manual didático na sua roupagem contemporânea. (SOUZA, 2010, p.129-130)

Nesse sentido, acredita-se que o objetivo de ensinar literatura, visando a uma formação crítica e a transformação da sociedade, como pretende o método histórico, nunca será atingido com o manual didático, já que o que ele apresenta em termos de literatura reduz-se à negação, resumos e fragmentos, marcas para este momento da sociedade capitalista, atestadas nos manuais didáticos contemporâneos.

A tarefa aqui foi apontar o estado dessas reflexões como ferramentas subsidiárias para intervir rumo à superação dos manuais didáticos, bem como da própria sociedade que forjou esse instrumento. Afinal, não se pode deixar de sublinhar que a negação do texto literário é altamente positiva à formação de um homem pragmático e utilitarista, aos moldes da sociedade do capital. Assim, mais do que por qualquer outra razão, este estudo diz respeito a seguinte constatação: adotar a leitura de obras literárias consideradas clássicas é enfrentar os problemas sociais contemporâneos.

E é por isso que se defende o estudo da literatura por meio do texto clássico, visto que a leitura de grandes obras abre possibilidades humanizadoras: não nega, não resume, nem fragmenta. Assim, o que se espera como resultado da pesquisa é que se consiga refutar o manual didático. Afinal, esse instrumento não oferece, disponibiliza e nem desenvolve as armas para o enfrentamento histórico dos problemas sociais que nos assolam a todos.

\section{Referências}

ALVES, Gilberto Luiz. O pensamento burguês no Seminário de Olinda (1800 - 1836). Ibitinga, São Paulo: Humanidades, 1993. 
. A produção da escola pública contemporânea. Campo Grande, MS: Editora

$\overline{\text { UFMS }}$; Campinas, São Paulo: Autores Associados, 2001.

. O trabalho didático na escola moderna: formas históricas. Campinas, SP: Autores Associados, 2005.

ANÔNIMO. Lazarilho de Tormes. Tradução de Pedro Câncio da Silva. São Paulo: Página Aberta; Brasília, Consejeria de Educación de la Embajada de Espanha. 1992.

AZEVEDO, Fernando de. A educação e seus problemas. São Paulo: Melhoramentos, 1953.

BARRETO, F. e LAET, C. de. Antologia Nacional. Rio de Janeiro: Livraria Francisco Alves, 1951.

BURY, R. Philobiblon (Tradução, apresentação e glossário de Marcelo Rollemberg). Cotia, SP: Ateliê Editorial, 2004.

CERVANTES, M. Don Quijote de La Mancha. Edição comemorativa do IV Centenário. Real Academia Española/Edição e notas de Francisco Rico. São Paulo: Alfaguara, 2004.

COMENIUS. Didáctica Magna. Lisboa: Fundação Calouste Gulbenkian, 1985.

COUTINHO, A. Antologia Brasileira de Literatura. vol. I. 4. ed., Rio de Janeiro: Editora Distribuidora de Livros Escolares Ltda, 1970.

HOFF, Sandino. (Apresentação, tradução e notas). Ratke, Wolfgang. A nova arte de ensinar: (1571 - 1635) textos escolhidos. Campinas: Autores Associados, 2008. (Coleção Clássicos da Educação).

LE GOFF, Jacques. Os intelectuais na Idade Média. Tradução de Marcos de Castro. 3. ed., Rio de Janeiro: José Olympio, 2010.

LINS, Osman. Do ideal e da glória: problemas inculturais brasileiros. São Paulo: Summus, 1997.

LULL, R. Livro de Ordem de Cavalaria. Apresentação e tradução de Ricardo da Costa. São Paulo: Instituto Brasileiro de Filosofia e Ciências Raimundo Lúlio, 2010. Acesso: http://www.ricardocosta.com/textos/livrocav.htm

MACEDO, J. M. de. Um passeio pela cidade do Rio de Janeiro. Rio de Janeiro: Editora Planeta do Brasil, 2004.

MARX, K. e ENGELS, F. A ideologia alemã. 6 e.d., São Paulo: Hucitec, 1987.

MOLIÉRE. O tartufo; Escola de mulheres; O burguês fidalgo. Traduções de Jacy Monteiro, Millôr Fernandes, Octavio Mendes Cajado. São Paulo: Abril Cultural, 1983.

PINHEIRO, J. C. Fernandes. Curso elementar de litteratura nacional. Rio de Janeiro: Garnier, 1862.

Postillas de Rethorica e Poetica. 3. ed., Rio de Janeiro: Garnier. 1885.

PEDRERO-SÁNCHEZ, Maria Guadalupe. História da Idade Média: textos e testemunhos. São Paulo: Editora UNESP, 2000. 
PONCE, A. Educação e luta de classes. São Paulo: Cortez, 1985.

RATKE, W. A nova arte de ensinar: (1571 - 1635) textos escolhidos. Apresentação, tradução e notas de Sandino Hoff. Campinas: Autores Associados, 2008. (Coleção Clássicos da Educação).

REBELO, M. Antologia escolar brasileira. Rio de Janeiro: Departamento Nacional de Educação, 1967.

ROCHA LIMA. Ciclo ginasial de português. 3 e 4. Rio de Janeiro: Reper Editora, 1970.

ROMERO, Silvio. Compêndio de história da literatura brasileira. Colaboração de João Ribeiro. Organização de Luiz Antonio Barreto. Rio de Janeiro: Imago Ed., Universidade Federal de Sergipe, 2001. Edição comemorativa.

ROSA, M. G. S. NOGUEIRA, A. X. Cultura, literatura e língua nacional. São Paulo: Editora do Brasil S/A, 1976.

SAVIANI, D. Escola e democracia. Campinas-SP: Autores Associados, 2008. (Coleção educação contemporânea - Edição Comemorativa).

SOUZA, Ana A. Arguelho de. Manuais didáticos: formas históricas e alternativas de superação. In: BRITO, Silvia Helena Andrade de; CENTENO, Carla Villamaina; LOMBARDI, José Claudinei; SAVIANI, Dermeval (orgs). A organização do trabalho didático na história da educação. Campinas: Autores Associados, 2010.

Manuais didáticos de língua e literatura na modernidade: gênese e desenvolvimento histórico. Revista HISTEDBR on-line, Campinas-SP, v. 01, p. 6 -19, 2010.

Ensino de Literatura no Colégio Pedro II, no início do século XX: O Compêndio de História da Literatura Brasileira, de Silvio Romero e João Ribeiro. Anais Eletrônicos UFB - João Pessoa, 2012. Acesso em:

http://www.histedbr.fae.unicamp.br/acer_histedbr/seminario/seminario9/PDFs/3.39.pdf SPINA, Segismundo. A cultura literária medieval. São Paulo: Ed. Ateliê Editorial, 1997.

VECHIA, A. LORENZ, K. M. (orgs.) Programa de ensino da escola secundária brasileira: 1850-1951. Curitiba: Ed. do Autor, 1998.

VIEIRA, Affonso Lopes. O romance de Amadis. São Paulo: Martins Fontes, 1995. (Coleção Gandhãra)

VICENTE, G. Auto da barca do inferno. São Paulo: Objetivo, 1997.

Recebido: fevereiro-15 março-15 